\title{
Evaluation of central nervous system (CNS) depressant activity of methanolic extract of Commelina diffusa Burm. in mice
}

\author{
Tania Sultana, Md. Abdul Mannan* and Tajnin Ahmed
}

\begin{abstract}
Background: Commelina diffusa Burm. (Family: Commelinaceae) is usually known as "climbing dayflower or spreading dayflower" in Bangladesh. The plant is used in fever, malaria, insect, bug bites, rheumatoid arthritis, gonorrhea, influenza, and bladder infection etc. The present investigation was undertaken which deals with the evaluation of central nervous system (CNS) depressant activity of methanolic extract of $C$. diffusa in mice models.

Methods: The central nervous system (CNS) depressant activity of $C$. diffusa was evaluated by the classical models of depression as open field, hole cross, forced swimming, tail suspension, and thiopental sodium induced sleeping time tests in mice. The animals were divided into control, positive control, and three test groups containing five mice each. The test groups received extract at the doses of 50, 100, and $200 \mathrm{mg} / \mathrm{kg}$ body weight orally where as the control group received distilled water $(0.1 \mathrm{~mL} /$ mouse, p.o.). Diazepam (1 mg/kg, i.p.) was used as standard drug.

Results: It is clear that the plant extract significantly decreased the locomotor activity of mice in open field and hole cross tests when compared to the control $(p<0.05)$. It is observed that the extract showed significantly $(p<0.05)$ increased in immobility time in forced swimming and tail suspension tests in mice. In addition, the extract produced prolongs the sleeping time with onset of action in contrast to the control group.

Conclusions: The present work depicts the evaluation of possible CNS depressant activity of $C$. diffusa in mice models. The obtained results provide support for the use of this species in traditional medicine and warrants further pharmacological investigations that could lead to novel leads in future.
\end{abstract}

Keywords: Commelina diffusa, CNS depressant, Extract, Diazepam

\section{Background}

Depression is a widespread psychiatric ailment [1]. It is already expected to constitute the second largest source of global burden of disease after heart disease in 2020 [2]. The monoaminergic hypothesis of depression does not provide a full understanding of the progression, causes, and pharmacotherapy of depression [3]. Most accepted hypothesis of depression is postulated, and oxidative stress is suggested to be involved in the pathophysiology of depression [4]. According to WHO estimated, 121 million people suffer from clinical depression [5]. It occurs usually in the early adult life of patients with decrease in monoamine neurotransmitters

\footnotetext{
* Correspondence: manna.034@gmail.com

Department of Pharmacy, Stamford University Bangladesh, 51, Siddeswari Road, Dhaka -1217, Bangladesh
}

[6]. Medicinal plants therapies may be effective alternatives in the treatment of depression. It possesses least side effects compared to synthetic medicines [7]. It has contributed significantly towards the development of modern medicine. Recently, traditional medicine is being re-evaluated by extensive research on different plant species and their active therapeutic principles in worldwide. The rich wealth of plant kingdom can represent a novel source of newer compounds with significant therapeutic activities. The most important merits of herbal medicine seem to be their perceived efficacy, low adverse effects, and low cost [8].

Commelina diffusa Burm. (Family: Commelinaceae) is a pan tropical herbaceous plant, which is known as "climbing dayflower or spreading dayflower" in Bangladesh. [9, 10].This herb is widely distributed 
throughout in Bangladesh and other South Asian countries. It is widely used in urinary tract infections, swellings, inflammation, diarrhoea, hemorrhoids, enteritis, eye irritation, conjunctivitis and ophthalmia. The juice of stem is used in laryngitis, sore throats, acute tonsillitis, pharyngitis, otitis media, and nose bleeding. Topically or internally, the plant is used in abscess, boils, fever, malaria, insect, snake, bug bites, rheumatoid arthritis, mumps, gonorrhea, common cold, cough, coughing up blood, influenza, bladder infection, and edema. Throughout Latin America, the plant parts are used in dermatitis and burns [11]. In Nepal, it is used to treat hemorrhoids, inflamed uterus, laryngitis, leprosy, malaria, mumps, otitis media, painful menses, pharyngitis, rheumatoid arthritis, sore throats, snake bites, tonsillitis and tumors. In Egypt, the weed is used as a refrigerant, tonic for treating stomach and groin problems [12]. In Caribbean Indians, the plant is used as a tea to ward off influenza and medicinal baths. In Mexico, it is used for the treatment of conjunctivitis, dermatitis, dysmenorrheal. In Paraguay, it is used for enteritis, gonorrhea, and infertility treatments. In the Dominican Republic, Haiti, and South America, it is used for kidney ailments, leucorrhea, malaria, nervous conditions, post partum discomfort, tuberculosis, tumors, and venereal diseases. The tiny blue flowers are boiled in Ecuador and Peru to make a tea for the relief of headaches [13]. In Trinidad, it is used as a depurative, bladder infection and cooling medicinal infusions. In the Windward Islands and Cuba, it is used for the treatment of jaundice in young children [14]. According to previous studies; $C$. diffusa exhibited good antimicrobial activity against a range of Grampositive and Gram-negative bacteria as well as fungi [15]. The anti-inflammatory activity of the extract tested using the chick carrageenan-induced foot oedema model. [16]. It also demonstrated protection of MRC-5 cells against oxidation by reactive oxygen species [17]. Another study mentioned that the extract is used for the treatment of cancer [18], antidiabetes [19], leprosy, and nervous system related disorders [20].

However, there is lack of scientific report to support these supposed central nervous system (CNS) depressant activity in mice. The present investigation was undertaken which deals with the evaluation of central nervous system (CNS) depressant activity of methanolic extract of $C$. diffusa Burm. in mice models.

\section{Methods}

\section{Chemicals}

The following drugs and chemicals were used in this study: Diazepam (Square Pharmaceutical Ltd., Bangladesh), Thiopental sodium (Gonoshastha Pharmaceuticals Ltd., Bangladesh), Methanol (Sigma Chemicals Co., USA). Diazepam (1 mg/kg i.p.) was used in open field, hole cross, forced swimming, tail suspension and thiopental sodium-induced sleeping time tests. The drugs were intraperitoneally (i.p.) administered $15 \mathrm{~min}$ before the experiment. The extract was orally administered $30 \mathrm{~min}$ before the experiment (Except open field, and hole cross tests) at the doses of 50, 100, and $200 \mathrm{mg} / \mathrm{kg}$, where as the animal of control group received distilled water $(0.1 \mathrm{~mL} / \mathrm{mouse}$, p.o. $)$.

\section{Collection of plant materials}

The plant was accumulated from the village of Roypur of Chuadanga district in January 2016 when weed beds were in their maximum densities. The whole plant with leaves, stems and roots was collected and analyzed by the proficient of Bangladesh National Herbarium, Mirpur, Dhaka, Bangladesh, where a voucher specimen (Accession No: 42,861) has been deposited for future reference.

\section{Preparation of extraction}

The whole plant was intensively washed with water. The adulterants were removed to obtain fresh sample. The collected samples were cut and sliced, if necessary. The samples were dried for 7 days in hot air oven at laboratory conditions. After drying, the dried samples were grounded to coarse powder with an electrical grinder. The powder sample was soaked in adequate amount of methanol for three days at room temperature with infrequent stirring and shaking. The solvent was filtered 3 times through a Whatman No. 1 filter paper and sterilized cotton bed. Then, the solvent was fully removed and obtained crude extract, which was used for the investigation of phytochemical screening and evaluation of central nervous system (CNS) depressant activity in mice models.

\section{Test animals}

Swiss albino mice, 3-4 weeks of age, weighing between 20 and $25 \mathrm{~g}$, were used in this study. These mice were collected from Pharmacology Laboratory, Jahangirnagar University, Savar, Dhaka, Bangladesh. Animals were kept in polyvinyl cages with soft wood bedding materials. Animals were well maintained under standard environmental conditions (temperature: $25 \pm 2{ }^{\circ} \mathrm{C}$, relative humidity: $55-65 \%$ and $12 \mathrm{~h}$ light/dark cycle). The animals were habituated to the laboratory environment for a period of 14 days prior to performing the experiments. All the experimental mice were treated following the Ethical Principles and Guidelines for Scientific Experiments on Animals (1995) formulated by The Swiss Academy of Medical Sciences and the Swiss Academy of Sciences. The Institutional Animal Ethical Committee (SUB/ IAEC/17.02) of Stamford University Bangladesh approved all experimental rules. 


\section{Acute toxicity test}

Mice were divided into a control and three test groups $(n=5)$. The test groups received extract orally at the doses of 500, 1000, and $2000 \mathrm{mg} / \mathrm{kg}$ body weight. After administration, the animals were kept in separate cages and were allowed to food and water ad libitum. The animals were then observed for possible behavioral changes, allergic reaction (skin rash, itching) and mortality for the next $72 \mathrm{~h}[21]$.

\section{Phytochemical screening}

Methanolic extract of $C$. diffusa was qualitatively tested for the detection of alkaloids, flavonoids, saponins, tannins, cardiac glycosides, carbohydrates, reducing sugars, proteins, glucosides, terpenoids, and steroids [22].

\section{Pharmacological tests \\ Open field test}

The open field test is used to measure the locomotion in mice by the number of square cross. The animals were divided into control, positive control and three test groups containing five mice each. The test groups received extract at the doses of 50,100, and $200 \mathrm{mg} / \mathrm{kg}$ body weight orally where as the control group received distilled water $(0.1 \mathrm{~mL} / \mathrm{mouse}$, p.o.). Diazepam $(1 \mathrm{mg} / \mathrm{kg}$, i.p.) used as positive control group. The open field was divided into a series of squares. Each square is separately colored black and white. The apparatus had a wall of $40 \mathrm{~cm}$ height. The animals were visited the squares and the number of visited squares were counted for $3 \mathrm{~min}$ at 0, 30, 60, 90 and 120 min intervals [23].

\section{Hole cross test}

A case having a size of $(30 \times 20 \times 14 \mathrm{~cm})$ with a wood partition fixed in the middle was used. The cage had a hole of $3 \mathrm{~cm}$ diameter at a height of $7.5 \mathrm{~cm}$ in the center. The animals were divided into control, positive control, and three test groups containing five animals in each. The test groups received extract at the doses of 50, 100 , and $200 \mathrm{mg} / \mathrm{kg}$ body weight orally and the control group received distilled water $(0.1 \mathrm{~mL} /$ mouse, p.o.). The standard drug diazepam ( $1 \mathrm{mg} / \mathrm{kg}$, i.p.) was used as positive control group. The mice were passed through the hole from one chamber to another and the number of passage was counted for $3 \mathrm{~min}$ at $0,30,60,90$, and $120 \mathrm{~min}$ intervals respectively [24].

\section{Forced swimming test}

The forced swimming test is commonly used assays of antidepressant-like activity in rodents. Animals were randomly divided into five groups. Thirty minutes later, the treatment with the extract $(50,100$, and $200 \mathrm{mg} / \mathrm{kg}$, p.o.) or diazepam (1 mg/kg, i.p.), a standard drug, or distilled water $(0.1 \mathrm{~mL} /$ mouse, p.o.), mice were individually placed in an open cylindrical container $(45 \mathrm{~cm}$ height $x$ $20 \mathrm{~cm}$ diameter) containing $17 \mathrm{~cm}$ of water at $25{ }^{\circ} \mathrm{C}$ for $5 \mathrm{~min}$. Mice were recorded as immobile when floating motionless or making only those movements necessary to keep the head above water [25].

\section{Tail suspension test}

This behavior displayed in rodents subjected to unavoidable and inescapable stresses during tail suspension test reflects behavioral despair, which reflects depression in humans. Mice were divided into five groups. Thirty minutes later, the extract (50, 100, and $200 \mathrm{mg} / \mathrm{kg}$, p.o.) was used as test groups. The diazepam $(1 \mathrm{mg} / \mathrm{kg}$, i.p.) was used as standard drug when the control group received distilled water $(0.1 \mathrm{~mL} /$ mouse, p.o.). Mice were suspended $50 \mathrm{~cm}$ above the floor using adhesive tape placed approximately $1 \mathrm{~cm}$ from the tip of their tails. The duration of immobility time was recorded for $6 \mathrm{~min}$. The mice were considered immobile when they passively hung or stayed motionless [26].

\section{Thiopental sodium-induced sleeping time test}

In this test, the animals were assigned for five groups comprising of five mice in each group. The test groups expected the extract at the doses of 50, 100, and $200 \mathrm{mg} / \mathrm{kg}$ when the control group received distilled water $(0.1 \mathrm{ml} / \mathrm{mouse}$, p.o.). The standard drug diazepam ( $1 \mathrm{mg} / \mathrm{kg}$, i.p.) was used as positive control group. After passing thirty minutes, each mouse was treated with thiopental sodium (40 mg/kg, i.p.) to induce sleep. The rodents were monitored by placing them on different chambers for the latent period (time between thiopental sodium administrations to loss righting reflex) and duration of sleeping time (time between the loss and recovery of righting reflex) [27].

\section{Statistical analysis}

The results were presented as mean \pm SEM. The statistical analysis was performed using one way analysis of variance (ANOVA) followed by Dunnett's post hoc test as using SPSS 18.00 software. Differences between groups were considered significant at a level of $* p<0.05$.

\section{Results \\ Phytochemical screening}

Phytochemical screening of the methanolic extract of $C$. diffusa revealed the presence of alkaloids, flavonoids, saponins, tannins, cardiac glycosides, terpenoids, and steroids (Table 1 ).

\section{Acute toxicity}

There was no mortality up to $2000 \mathrm{mg} / \mathrm{kg}$ dose. It was observed that there was significant reduction in the activity of animals from $1 / 2 \mathrm{~h}$ up to $4 \mathrm{~h}$ and subsequently 
Table 1 Preliminary qualitative phytochemical screening of methanolic extract of $C$. diffusa (MECD)

\begin{tabular}{ll}
\hline Plant constituents & Inference \\
\hline Alkaloids & + \\
Flavonoids & + \\
Saponins & + \\
Tannins & + \\
Cardiac glycosides & + \\
Carbohydrates & - \\
Reducing sugars & - \\
Proteins & - \\
Glucosides & - \\
Terpenoids & + \\
Steroids & + \\
\hline
\end{tabular}

+: Presence; -: Absence

they were normal. Therefore, it can be assumed that MECD possesses a low toxicity profile and the $\mathrm{LD}_{50}$ is more than $2000 \mathrm{mg} / \mathrm{kg}$.

\section{Open field test}

The extract significantly decreased the locomotor activity in mice at the doses of 50,100, and $200 \mathrm{mg} / \mathrm{kg}$ body weight $(p<0.05)$ and this effect was evident from the initial observation $(0 \mathrm{~min})$ period and continued up to 5 th observation period (120 min) (Table 2). Diazepam $(1 \mathrm{mg} / \mathrm{kg}$, i.p.) showed a noticeable decrease in locomotion in mice from the $2{ }^{\text {nd }}$ observation period to 5 th observation period as expected.

\section{Hole cross test}

Methanolic extract of $C$. diffusa showed significant decrease of movement at the doses of 50, 100, and $200 \mathrm{mg} / \mathrm{kg}$ body weight from its initial value at $0 \mathrm{~min}$ to $120 \mathrm{~min}(p<0.05)$. The number of hole crossed from one chamber to another by mice of the standard drug diazepam (1 $\mathrm{mg} / \mathrm{kg}$, i.p.) is decreased from $0 \mathrm{~min}$ to $120 \mathrm{~min}$ (Table 3 ). The extract showed dose dependent activity and maximum depressive effect was observed at 5 th observation period.

\section{Forced swimming test}

After oral administration, the extract at the doses of 50 , 100 , and $200 \mathrm{mg} / \mathrm{kg}$ significantly increased the immobility times when compared with the control group $(p<$ 0.05) (Table 4). Similarly, the standard drug diazepam (1 mg/kg, i.p.), as expected, showed a significant increase in the immobility times $(p<0.05)$.

\section{Tail suspension test}

The extract at the doses of 50, 100, and $200 \mathrm{mg} / \mathrm{kg}$ produced a significant increase in the immobility times when compared to control group $(p<0.05)$. The effect of the extract on behavior in this test is shown in Table 5. Diazepam (1 $\mathrm{mg} / \mathrm{kg}$, i.p.), the duration of immobility time was compared with control group which showed significant increase in immobility times $(p<0.05)$.

\section{Thiopental sodium-induced sleeping time test}

The plant extract decreased the onset of action time and increased the length of the sleeping time, which was comparable to the control group (Table 6). The extract produced a significant effect on the duration of sleeping times. The standard drug diazepam ( $1 \mathrm{mg} / \mathrm{kg}$, i.p.), was also showed a statistically significant effect on the onset of sleep and the duration of sleeping times $(p<0.05)$.

\section{Discussion}

The present study was conducted to explicate central nervous system (CNS) depressant activities of the methanolic extract of $C$. diffusa in mice. The CNS depressant effect of $C$. diffusa was studied using five neuropharmacological models namely open field, hole cross, forced swimming, tail suspension, and thiopental sodium induced sleeping time tests. These paradigms are widely used classical models for screening neuropharmacological activity.

The methanolic extract of $C$. diffusa decreased the frequency and amplitude of movements in the open field and hole cross tests in mice. The results of these study provided evidence that the extract reduced locomotor activity confirming its CNS depressant effects. Locomotor activity is considered as an index of alertness and

Table 2 Effects of $C$. diffusa extract and diazepam on the open field test

\begin{tabular}{|c|c|c|c|c|c|c|}
\hline \multirow[t]{2}{*}{ Treatment } & \multirow{2}{*}{$\begin{array}{l}\text { Dose } \\
(\mathrm{mg} / \mathrm{kg})\end{array}$} & \multicolumn{5}{|c|}{ Number of square crossed } \\
\hline & & $0 \mathrm{~min}$ & $30 \mathrm{~min}$ & $60 \mathrm{~min}$ & $90 \min$ & $120 \mathrm{~min}$ \\
\hline Control & $0.1 \mathrm{~mL} / \mathrm{mouse}$ & $76.00 \pm 1.64$ & $72.20 \pm 3.48$ & $61.00 \pm 2.66$ & $41.40 \pm 1.07$ & $32.60 \pm 1.36$ \\
\hline Diazepam & 1 & $71.80 \pm 3.26$ & $55.80 \pm 2.69^{*}$ & $30.40 \pm 2.04^{*}$ & $15.00 \pm 0.70^{*}$ & $6.80 \pm 0.58^{*}$ \\
\hline MECD & 50 & $59.80 \pm 1.96$ & $49.00 \pm 4.19^{*}$ & $44.00 \pm 1.22^{*}$ & $27.60 \pm 1.12^{*}$ & $15.40 \pm 0.74^{*}$ \\
\hline MECD & 100 & $56.40 \pm 2.42$ & $43.20 \pm 1.28^{*}$ & $40.40 \pm 2.06^{*}$ & $19.60 \pm 0.92^{*}$ & $9.80 \pm 0.66^{*}$ \\
\hline MECD & 200 & $63.60 \pm 1.93$ & $51.00 \pm 1.76^{*}$ & $33.60 \pm 1.83^{*}$ & $17.40 \pm 0.92^{*}$ & $8.20 \pm 0.58^{*}$ \\
\hline
\end{tabular}

Values are presented as mean \pm SEM $(n=5)$. MECD $=$ Methanolic extract of $C$. diffusa

${ }^{*} p<0.05$, vs. control (Dunnett's test) 
Table 3 Effects of C. diffusa extract and diazepam on hole cross test

\begin{tabular}{|c|c|c|c|c|c|c|}
\hline \multirow[t]{2}{*}{ Treatment } & \multirow{2}{*}{$\begin{array}{l}\text { Dose } \\
\text { (mg/kg) }\end{array}$} & \multicolumn{5}{|c|}{ Number of hole crossed } \\
\hline & & $0 \mathrm{~min}$ & $30 \mathrm{~min}$ & $60 \mathrm{~min}$ & $90 \mathrm{~min}$ & $120 \mathrm{~min}$ \\
\hline Control & $0.1 \mathrm{~mL} / \mathrm{mouse}$ & $16.40 \pm 0.92$ & $12.40 \pm 1.12$ & $9.40 \pm 0.51$ & $6.60 \pm 0.81$ & $4.00 \pm 0.70$ \\
\hline Diazepam & 1 & $14.00 \pm 1.41$ & $5.40 \pm 0.51^{*}$ & $3.40 \pm 0.24^{*}$ & $1.20 \pm 0.37^{*}$ & $0.60 \pm 0.24^{*}$ \\
\hline MECD & 50 & $14.40 \pm 1.69$ & $7.60 \pm 0.40^{*}$ & $6.20 \pm 1.02^{*}$ & $3.00 \pm 0.54^{*}$ & $2.40 \pm 0.51$ \\
\hline MECD & 100 & $13.40 \pm 0.92$ & $6.60 \pm 0.74^{*}$ & $5.00 \pm 0.89^{*}$ & $2.40 \pm 0.67^{*}$ & $1.60 \pm 0.51^{*}$ \\
\hline MECD & 200 & $15.00 \pm 0.83$ & $6.40 \pm 0.51^{*}$ & $4.20 \pm 0.37^{*}$ & $1.80 \pm 0.37^{*}$ & $1.00 \pm 0.31^{*}$ \\
\hline
\end{tabular}

Values are presented as mean \pm SEM $(n=5)$. MECD $=$ Methanolic extract of $C$. diffusa

${ }^{*} p<0.05$, vs. control (Dunnett's test)

a reduction of it is an indicative of CNS depressant activity [28]. It is a measurement of the level of excitability of the CNS [29], this decrease in spontaneous motor activity could be attributed to the CNS depressant effect of the plant extract [30]. Both tests significantly decreased locomotion in mice. Gamma amino butyric acid is the major inhibitory neurotransmitter in the central nervous system [31], which is involved in the physiological functions related to the psychological and neurological disorders as epilepsy, depression, parkinson syndrome, and alzheimer's disease [32]. Diverse drugs might modify the GABA system, at the level of the synthesis of it by potentiating the GABA-mediated postsynaptic inhibition through an allosteric modification of GABA receptors. It directly increases in chloride conductance or indirectly by potentiating GABA-induced chloride conductance with simultaneous depression of voltage activated $\mathrm{Ca}^{2}$ ${ }^{+}$channel like barbiturates [33]. Therefore, it is predictable that the extract may act by potentiating GABAergic inhibition in the CNS via membrane hyper polarization leading to a reduction in the firing rate of critical neurons in the brain or it may be due to direct activation of GABA receptors [31]. It may also be due to enhanced affinity for GABA or an increase in the duration of the GABA-gated channel opening [34].

The forced swimming test is widely used for the assessment of antidepressant-like activity in animal models. The shortening of immobility duration indicates antidepressant activity in this model, while prolonged immobility time reflects a CNS depression-like effect

Table 4 Effects of C. diffusa extract and diazepam on forced swimming test

\begin{tabular}{lll}
\hline Treatment & Dose $(\mathrm{mg} / \mathrm{kg})$ & Immobility time $(\mathrm{s})$ \\
\hline Control & $0.1 \mathrm{~mL} / \mathrm{mouse}$ & $62.00 \pm 2.92$ \\
Diazepam & 1 & $177.00 \pm 2.55^{*}$ \\
MECD & 50 & $73.20 \pm 1.99$ \\
MECD & 100 & $87.20 \pm 3.61^{*}$ \\
MECD & 200 & $141.40 \pm 4.25^{*}$ \\
\hline
\end{tabular}

Values are presented as mean \pm SEM $(n=5)$. MECD = Methanolic extract of C. diffusa

${ }^{*} p<0.05$, vs. control (Dunnett's test)
[35]. However, CNS depressant effect was observed in the forced swimming test. Additionally, the experiment was extended to observe the tail suspension test allow as a fast and reliable screening of the psychotropic properties of drugs. Basically, the measuring principle is based on the energy developed by mice trying to escape from their suspension. During this test, the movements of the mice were analyzed in terms of energy and power developed over time. The extract was significantly increased in immobility time which indicated as CNS depressant effects in mice. The standard drug diazepam also indicated CNS depressant effects in mice model. It has been argued that tail suspension test is less stressful than force swimming test and has greater pharmacological sensitivity. The results obtained from tail suspension test is in concordance with the validated forced swimming test by Porsolt et al. Environmental factors and hereditary factors play a major role in producing deficient monoaminergic transmission in the CNS there by producing symptoms of depression [36].

Previous phytochemical investigation suggests that flavonoids and neuroactive steroids are ligands for $\mathrm{GABA}_{\mathrm{A}}$ receptors in the CNS which indicates that they can act as benzodiazepine-like agents [37]. It has also been reported that some flavanoids exhibit high affinity binding to the benzodiazepine site of $\mathrm{GABA}_{\mathrm{A}}$ receptors. Therefore, the CNS depressant activity may be due to the phytoconstituents present in the extract of $C$. diffusa. Triterpenoids, and saponins are reported to have agonistic activities at $\mathrm{GABA}_{\mathrm{A}}$ receptor complex [33, 38, 39].

Table 5 Effects of $C$. diffusa extract and diazepam on tail suspension test

\begin{tabular}{lll}
\hline Treatment & Dose $(\mathrm{mg} / \mathrm{kg})$ & Immobility time $(\mathrm{s})$ \\
\hline Control & $0.1 \mathrm{~mL} / \mathrm{mouse}$ & $84.80 \pm 2.41$ \\
Diazepam & 1 & $219.80 \pm 3.98^{*}$ \\
MECD & 50 & $106.00 \pm 2.12^{*}$ \\
MECD & 100 & $130.80 \pm 2.22^{*}$ \\
MECD & 200 & $191.20 \pm 2.35^{*}$ \\
\hline
\end{tabular}

Values are presented as mean \pm SEM $(n=5)$. MECD $=$ Methanolic extract of C. diffusa

${ }^{*} p<0.05$, vs. control (Dunnett's test) 
Table 6 Effects of C. diffusa extract and diazepam on thiopental sodium-induced sleeping time test

\begin{tabular}{llll}
\hline Treatment & Dose $(\mathrm{mg} / \mathrm{kg})$ & Onset of action $(\mathrm{min})$ & Duration of sleeping time $(\mathrm{min})$ \\
\hline Control & $0.1 \mathrm{~mL} / \mathrm{mouse}$ & $4.95 \pm 0.41$ & $27.00 \pm 1.92$ \\
Diazepam & 1 & $3.01 \pm 0.13^{*}$ & $91.20 \pm 1.93^{*}$ \\
MECD & 50 & $4.78 \pm 0.22$ & $38.80 \pm 1.36^{*}$ \\
MECD & 100 & $4.56 \pm 0.22$ & $46.80 \pm 1.28^{*}$ \\
MECD & 200 & $3.74 \pm 0.24^{*}$ & $76.20 \pm 2.15^{*}$ \\
\hline
\end{tabular}

Values are presented as mean \pm SEM $(n=5)$. MECD $=$ Methanolic extract of $C$. diffusa

${ }^{*} p<0.05$, vs. control (Dunnett's test)

These phytoconstituents may be contributed to the CNS depressant effects in mice. There is no strict evidence which substances are exactly responsible for the CNS depressant effects.

Thiopental sodium belongs to the barbiturate and induces sleep in both humans and rodents. The thiopental sodium induced sleeping time test in mice was used to investigate the sedative-hypnotic drugs [40]. It binds with GABA receptor complex and shows GABA mediated hyper polarization of postsynaptic neurons [40]. It potentiates GABA activity, entering chloride into the neuron by prolonging the duration of chloride channel opening. On the other hand, thiopental can block excitatory glutamate receptors. All of these molecular action lead to decrease of neuronal activity that support the following reference substances which possess CNS depressant action. Our results demonstrate a relationship between the CNS depressant effect of $C$. diffusa and diazepam which could be suggested in this test.

\section{Conclusions}

The present work depicts the evaluation of possible CNS depressant activity of $C$. diffusa in mice models. The obtained results provide support for the use of this species in traditional medicine and warrants further pharmacological investigations that could lead to novel leads in future.

\section{Acknowledgements}

The authors are grateful to Professor Dr. Bidyut Kanti Datta, Chairman, Department of Pharmacy, Stamford University Bangladesh for his permission to use the facilities of the Pharmacology and Phytochemistry Laboratory.

\section{Authors' contributions}

MAM designed and coordinated all laboratory experiments, analyzed and interpreted results. MAM and TS conducted all experiments. MAM did statistical analysis and drafted the manuscript. All authors read and approved the manuscript.

\section{Ethics approval}

The manuscript does not contain any individual person's data in any form. So, this information is not relevant.

All the experimental mice were treated following the Ethical Principles and Guidelines for Scientific Experiments on Animals (1995) formulated by The Swiss Academy of Medical Sciences and the Swiss Academy of Sciences. The Institutional Animal Ethical Committee (SUB/IAEC/17.02) of Stamford University Bangladesh approved all experimental rules.
Competing interests

The authors report no conflicts of interest. The authors alone are responsible for the content and writing of the paper.

\section{Publisher's Note}

Springer Nature remains neutral with regard to jurisdictional claims in published maps and institutional affiliations.

Received: 10 July 2017 Accepted: 22 January 2018

Published online: 29 January 2018

\section{References}

1. Ferrari AJ, Charlson FJ, Norman RN, Patten SB, Freedman G, CGL M, Vos T, Whiteford HA. Burden of depressive disorders by country, sex, age, and year: findings from the global burden of disease study 2010. PLoS Med. 2013; 10(11):1-12

2. Smith AJ, Sketris I, Cooke C, Gardner D, Kisely S, Tett SE. A comparison of antidepressant use in Nova Scotia, Canada and Australia. Pharmacoepidemiol Drug Saf. 2008;17(7):697-706.

3. Schildkraut JJ, Gordon EK, Durell J. Catecholamine metabolism in affective disorders. I. Normetanephrine and VMA excretion in depressed patients treated with imipramine. J Psychiatr Res. 1965;3(4):213-28.

4. Michel TM, Frangou S, Thiemeyer D, Camara S, Jecel J, Nara K, Brunklaus A, Zoechling R, Riederer P. Evidence for oxidative stress in the frontal cortex in patients with recurrent depressive disorder-a postmortem study. Psychiatry Res. 2007;151(1-2):145-50.

5. Cryan JF, Lucki I. Antidepressant like behavioral effects mediated by hydroxy tryptamine receptors. The Journal of Pharmacology experimental Therapeutics. 2000;295:1120-6.

6. Dhingra D, Sharma A. Review on antidepressant plants. Natural Products Radiance. 2005:144-52.

7. Zhang J, Wu J, Fujita Y, Yao W, Ren Q, Yang C, Li S, Shirayama Y, Hashimoto K. Antidepressant effects of TrkB ligands on depression-like behaviour and dendritic changes in mice after inflammation. Int J Neuropsychopharmacol. 2015:1-12.

8. Ghani A. Medicinal plants of Bangladesh. The Asiatic Society of Bangladesh: Dhaka; 1998.

9. Akobundu IO, Agyakwa C. A handbook of west African weeds. Ibadan (Nigeria): International institute of tropical agriculture; 1987.

10. Burkill HM. The useful plants of west tropical Africa. Edition Royal Botonaic Gardens Kew: London. 1985:431-2.

11. David BLAc. Medicine at your feet: Healing plants of the Hawaiian Kingdom Commelina diffusa (Honohono); 1998. http://www.medicineatyourfeet.com/

12. Leonard DB. Medicine at your feet: Healing plants of the Hawaiian Kingdom. 2012;1. http://www.medicineatyourfeet.com/

13. Seaforth $C E$, Adams $C D$, Sylvester $Y$. A guide to the medicinal plants of Trinidad and Tobago. Commonwealth Science Council, Commonwealth Secretariat, London, UK. 1983; p:222.

14. Beira A, Leon MC, Iglesias E, Ferrandiz D, Herrera R, Volpato G, Godinez D, Guimarais M. Alvarez R. Estudios etnobotanicos sobre plantas medicinales en la provincia de Camaguey (Cuba) Anales del Jardín Botánico de Madrid. 2004:61(2):185-203.

15. Khan MAA, Islam MT, Sadhu SK. Evaluation of phytochemical and antimicrobial properties of Commelina diffusa Burm. f. Orient Pharm Exp Med 2011;11 (4):235-241. 
16. Mensah AY, Houghton PJ, Dickson RA, Fleischer TC, Heinrich M, Bremner P. In vitro evaluation of effects of two Ghanaian plants relevant to wound healing. Phytother Res. 20(11):941-4.

17. Houghton PJ, Hylands PJ, Mensah AY, Hensel A, Deters AM. In vitro tests and ethnopharmacological investigations: wound healing as an example. J Ethnopharmacol. 2005;100(1):100-7.

18. Plants HJL. Used against cancer. A survey. Lloydia. 1969;32:247-96.

19. Youn JY, Park HY, Cho HK. Anti-hyperglycemic activity of Commelina communis L.: inhibition of a-glucosidase. Diabetes Res Clin Pract. 2004;66:149-55.

20. Oudhia, P. Kaua-kaini (Commelina benghalensis Linn.) Society for Parthenium Management(SOPAM) 28-A, Greeta Nagar, Raipur - 492001 India.2004.

21. Walker CIB, Trevisan G, Rossato MF, Franciscato C, Pereira ME, Ferreira J, Manfron MP. Antinociceptive activity of Mirabilis jalapa in mice. J Ethnopharmacol. 2008;120:169-75.

22. Ghani A. Medicinal plants of Bangladesh with chemical constituents and uses. 2nd ed. Dhaka, Bangladesh: The Asiatic Society of Bangladesh; 2003. p. 331-2.

23. Gupta BD, Dandiya PC, Gupta ML. A psychopharmacological analysis of behavior in rat. Japan J Pharm. 1971;21:293-8.

24. Takagi K, Watanabe M, Saito H. Studies on the spontaneous movement of animalsby the hole cross test: effect of 2-dimethylaminoethane. Its acylates on the central nervoussystem. Jpn J Pharmacol. 1971;21:797-810.

25. Porsolt RD, Bertin A, Behavioural JM. Despair in mice: a primary screening test for antidepressants. Archives Internationales de Pharmacodynamie et de Therapie. 1977;229:327-36.

26. Steru L, Chermat R, Thierry B, Simon P. The tail suspension test: a new method for screening antidepressants in mice. Psychopharmacology. 1985; 85:367-70.

27. Hossain MM, Hasan SMR, Akter R, Islam MN, Saha MR, Rashid MJ, Saha MR, Mazumder MEH, Rana S. Evaluation of analgesic and neuropharmacological properties of the aerial part of Tinospora cordifolia miers.In mice. Stam J Pharma Scis. 2009;2:31-7.

28. Protapaditya D, Sangita C, Priyanka C, Sanjib B. Neuropharmacological properties of Mikania scandens (L.) Willd. (Asteraceae). Journal of Advanced Pharmaceutical Technology and Research. 2011;2(4):255-9.

29. Mansur R, Martz W, Effects CE. Of acute and chronic administration of Cannabis Satis and (-) 9-transtetrahydrocannabinaol on the behaviour of rats in open field arena. Psychopharmacol. 1980:2:5-7.

30. Rakotonirina VS, Bum EN, Rakotonirina A, Bopelet M. Sedative properties of the decoction of the rhizome of Cyperus articulatus. Fitoterapia. 2001;72:22-9.

31. Kavita G, Vijay KL, Shivesh J. Anticonvulsant potential of ethanol extracts and their solvent partitioned fractions from Flemingia strobilifera root. Pharm Res. 2013;5(4):265-70.

32. Kumar K, Sharma S, Kumar P, Deshmukh R. Therapeutic potential of GABA(B) receptor ligands in drug addiction, anxiety, depression and other CNS disorders. Pharmacol Biochem Behav. 2013;110:174-84.

33. Uma AB, Radha Y, Prachi DP, Mandar RZ, Rahul SS. Study of central nervous system depressant and behavioral activity of an ethanol extract of Achyranthes aspera(Agadha) in different animal models. International Journal of Applied and Basic Medical Research. 2011;1 (2):104-8.

34. Shans-Ud-Doha KM, Zobaer AM, Sitesh CB, Nazmul Q Antinociceptive, antiinflammatory, antimicrobialand central nervous system depressant activities of ethanolic extract of leaves and roots of Gomphostemma parviflorum var. parviflorum wall. Pharm Res. 2013;5(4):233-40.

35. Subarnas A, Tadano T, Nakahata N, Arai Y, Kinemuchi H, Oshima Y, Kisara K, Ohizumi Y. A possible mechanism of antidepressant activity of beta-amyrin palmitate isolated from Lobelia inflates leaves in the forced swimming test. Life Sci. 1993;52:289-96.

36. Dhingra D, Sharma A. Evaluation of antidepressant-like activity of glycyrrhizin in mice. Indian J Pharmacol. 2005;37(6):390-4.

37. Protapaditya D, Sangita C, Priyanka C, Sanjib B. Neuropharmacological properties of Mikania Scandens (L.) Willd. (Asteraceae). Journal of Advanced Pharmaceutical Technology and Research. 2011;2(4):255-9.

38. Kumaresan PT, Asish T, Vijaya C. Neuropharmacological activity of Lippia nodiflora Linn. Pharm Res. 2011;3(3):194-200.

39. Khatoon MM, Khatun MH, Islam ME, Parvin MS. Analgesic, antibacterial and central nervous system depressant activities of Albizia proceraleaves. Asian Pacific Journal of Tropical Biomedicine. 2014;4(4):279-84.

40. Huang F, Xiong Y, Xu L, Ma S, Dou C. Sedative and hypnotic activities of the ethanol fraction from Fructus schisandrae in mice and rats. J Ethnopharmacol. 2007:110:471-5.

\section{Submit your manuscript to a SpringerOpen ${ }^{\circ}$ journal and benefit from:}

- Convenient online submission

- Rigorous peer review

- Open access: articles freely available online

- High visibility within the field

- Retaining the copyright to your article

Submit your next manuscript at $\boldsymbol{\nabla}$ springeropen.com 